\title{
Postnatal uterine development in Inverdale ewe lambs
}

\author{
Kanako Hayashi, Anne R O'Connell ${ }^{1}$, Jennifer L Juengel ${ }^{2}$, Ken P McNatty ${ }^{3}$, George H Davis ${ }^{1}$, \\ Fuller W Bazer and Thomas E Spencer
}

Department of Animal Science, Center for Animal Biotechnology and Genomics, Texas A and M University, 442 Kleberg Center, 2471 TAMU, College Station, Texas 77843-2471, USA, ${ }^{1}$ AgResearch, Invermay Agricultural Centre, Private Bag, Mosgiel, New Zealand, ${ }^{2}$ AgResearch, Wallaceville Animal Research Centre, PO Box 40063, Upper Hutt, New Zealand and ${ }^{3}$ School of Biological Sciences, Victoria University, PO Box 600, Wellington, New Zealand

Correspondence should be addressed to K Hayashi; Email: kanako@tamu.edu

K Hayashi and A R O'Connell contributed equally to this work

\begin{abstract}
Postnatal development of the uterus involves, particularly, development of uterine glands. Studies with ovariectomized ewe lambs demonstrated a role for ovaries in uterine growth and endometrial gland development between postnatal days (PNDs) 14 and 56 . The uterotrophic ovarian factor(s) is presumably derived from the large numbers of growing follicles in the neonatal ovary present after PND 14. The Inverdale gene mutation (FecXI) results in an increased ovulation rate in heterozygous ewes; however, homozygous ewes (II) are infertile and have 'streak' ovaries that lack normal developing of preantral and antral follicles. Uteri were obtained on PND 56 to determine whether postnatal uterine development differs between wild-type $(++)$ and II Inverdale ewes. When compared with wild-type ewes, uterine weight of II ewes was $52 \%$ lower, and uterine horn length tended to be shorter, resulting in a $68 \%$ reduction in uterine weight:length ratio in II ewes. Histomorphometrical analyses determined that endometria and myometria of II ewes were thinner and intercaruncular endometrium contained $38 \%$ fewer endometrial glands. Concentrations of estradiol in the neonatal ewes were low and not different between ++ and II ewes, but II ewes had lower concentrations of testosterone and inhibin- $\alpha$ between PNDs 14 and 56. Receptors for androgen and activin were detected in the neonatal uteri of both ++ and II ewes. These results support the concept that developing preantral and/or antral follicles of the ovary secrete uterotrophic factors, perhaps testosterone or inhibin- $\alpha$, that acts in an endocrine manner to stimulate uterine growth and endometrial gland development in the neonatal ewes.

Reproduction (2008) 135 357-365
\end{abstract}

\section{Introduction}

Uterine development is initiated in the fetus; however, it is not completed until after birth in domestic animals, laboratory rodents, and humans (Bartol et al. 1999, Spencer et al. 2005a). A major developmental event in the neonatal uterus is the differentiation and development of the endometrial glands or adenogenesis (Gray et al. 2001b, Spencer et al. 2005b). Alteration or ablation of the endometrial glands and/or their secretory products compromises blastocyst survival and implantation (embryo/ fetus and associated extra-embryonic membranes) in the mouse, rat, and sheep (Stewart et al. 1992, Bartol et al. 1995, Zhu et al. 1998, Gray et al. 2001 c, 2002). In humans, the secretory products of the endometrial glands appear to be a primary source of nutrition for conceptus growth during the first trimester of pregnancy (Burton et al. 2002).

In sheep, uterine adenogenesis after birth involves budding and differentiation of the endometrial glandular epithelium (GE) from the luminal epithelium (LE), specification and development of the intercaruncular endometrial stroma, development of endometrial folds, and, to a lesser extent, growth of endometrial caruncles and myometrium (Wiley et al. 1987, Taylor et al. 2000). Endometrial adenogenesis begins between postnatal days (PNDs) 1 and 7 when shallow epithelial invaginations appear along the LE in presumptive intercaruncular areas. Between PNDs 7 and 14, the nascent GE buds proliferate into the stroma and form tubules or ducts that begin to coil and branch by PND 21 as they proliferate through the stroma toward the inner circular layer of the myometrium. By PND 56, uterine morphogenesis is essentially complete, as the aglandular caruncular and glandular intercaruncular endometrial areas are histoarchitecturally similar to that of the adult uterus. The caruncular areas of endometrium, which are the sites of superficial implantation and placentation for the formation of placentomes, do not contain glands. Uterine adenogenesis is a critical developmental event in ewes, because inappropriate exposure to progestins or estrogens from birth to PND 56 
permanently ablates endometrial gland development, resulting in a uterine gland knockout (UGKO) phenotype in the adult (Bartol et al. 1999, Gray et al. 2001 a, Carpenter et al. 2003b, Hayashi et al. 2004). The adult UGKO ewes are infertile and exhibit recurrent early pregnancy losses (Gray et al. 2001b, 2002). Therefore, it is important to understand the mechanisms regulating postnatal growth and differentiation of the uterus.

Postnatal ovine uterine development is complex and involves the endocrine actions of pituitary-derived prolactin, as well as a number of autocrine and paracrine actions of the uterine-derived growth factor systems including the fibroblast growth factors, hepatocyte growth factor, insulin-like growth factors (IGFs), and WNTs (Taylor et al. 2000, 2001, Carpenter et al. 2003b, Hayashi et al. 2005, Hayashi \& Spencer 2006). Experiments with ovariectomized ewe lambs established that the ovary also influences uterine growth and endometrial gland morphogenesis after PND 14 (Carpenter et al. 2003a). The neonatal ovine ovary contains both the preantral and antral ovarian follicles at birth, which decline on PND 14, increase to maximum numbers on PND 28, remain high from PNDs 42 to 56, and decline thereafter (Kennedy et al. 1974, Tassell et al. 1978). These changes in the ovarian follicular dynamics are temporally correlated with the ontogeny of endometrial gland development in the neonatal ewe (Wiley et al. 1987, Taylor et al. 2001). Estrogen is not likely to be the uterotrophic factor from the ovary, because the circulating levels of $17 \beta$-estradiol are essentially below the detectable limits after birth (Carpenter et al. 2003b). The uterotrophic ovarian factor presumably emanates from the large number of developing follicles in the ovary of the neonatal ewe. Indeed, in sheep, the activinfollistatin system has been implicated in ovarian regulation of neonatal uterine development and differentiation (Carpenter et al. 2003a, Hayashi et al. 2003).

The Inverdale ewe is a valuable model for investigating uterine development in the absence of factors that would normally be derived from developing ovarian follicles. The Inverdale high fecundity gene (FecXI), a major gene for prolificacy in sheep, was first identified in the descendants of a Romney ewe which consistently produced large litters that resulted from a dysfunctional mutation in bone morphogenetic protein 15 (BMP15) gene (Galloway et al. 2000). Ewes heterozygous for the FecXI gene $(I+)$ have an average of one more ovulation during each estrous cycle than the wild-type ewes $(++)$ and 0.6 more lambs per ewe lambing (Davis et al. 1991, Shackell et al. 1993). In the wild-type ewes, the first wave of ovarian follicle growth occurs in the fetus between days 100 and 120 of gestation (Juengel et al. 2002). However, homozygous (II) ewes are infertile and incapable of normal ovarian follicular development beyond the primary (type 2) stage (Braw-Tal et al. 1993b, Smith et al. 1997), resulting in a 'streak' ovary phenotype (Davis et al. 1992, Galloway et al. 2002).
In the adult II ewes, the circulating levels of folliclestimulating hormone (FSH) and luteinizing hormone (LH) are high and comparable with those for ovariectomized wild-type $(++)$ ewes, because the II ewes have very low circulating levels of $17 \beta$-estradiol and inhibin (Shackell et al. 1993). The mean ovarian volume in adult II ewes is about $77 \%$ less than that for the I+ or ++ genotypes (Smith et al. 1997). Moreover, uteri of 1.5-year-old II ewes are much smaller than those for ++ ewes (Davis et al. 1992). However, the circulating levels of FSH and $\mathrm{LH}$ are not different between the ++ and $\mathrm{I}+$ genotypes in either fetal or adult ewes. Furthermore, no differences in the ovarian secretion rates of inhibin, estradiol, and progesterone have been reported between the ++ and I+ genotypes (Shackell et al. 1993), suggesting that both ++ and I+ Inverdale ewes have similar levels of ovarian follicular activity (Smith et al. 1997). Thus, the effects of ovarian factors in I+ and ++ ewe lambs would be similar. Therefore, available evidence supports the working hypothesis that uterine growth and differentiation is compromised in homozygous Inverdale ewes due to the lack of uterotrophic ovarian factors.

The objective of this study was to test the hypothesis that the Inverdale gene mutation influences postnatal development of the uterus. The results from this study strongly support the hypothesis that a uterotrophic factor(s) from the developing ovarian follicles of the neonatal ewe acts in an endocrine manner to regulate postnatal growth and differentiation of the uterus.

\section{Results \\ Morphology and morphometry of neonatal ovary and uterus}

Ovary

The combined weight of the ovaries from II ewes was $87 \%$ lower $(P<0.002)$ than for ++ ewes on PND 56 (Table 1). As expected, the ovaries from II ewes were devoid of the antral follicles (data not shown).

\section{Uterus}

Uteri from II ewes weighed $48 \%$ less $(P<0.03)$ than those from ++ ewes (Table 1). Uterine length for II ewes tended $(P<0.07)$ to be shorter, and the weight:length ratio of the uteri was $68 \%$ less $(P<0.04)$ for II ewes.

\section{Uterine histoarchitecture}

Examples of differences in uterine histology are presented in Fig. 1, and the results of morphometric analyses are summarized in Table 1. When compared with the wild-type, the thickness of caruncular and intercaruncular areas of uterine endometrium was reduced by $16 \%$ $(P<0.03)$ and $34 \%(P<0.0001)$ respectively in II ewes. 
Table 1 Morphometric analyses of uteri from wild type $(++)$ and homozygous Inverdale (II) ewe lambs.

\begin{tabular}{|c|c|c|c|c|}
\hline Measurement & ++ & II & S.E.M. & $P$ value \\
\hline Ovarian weight (g) & 0.89 & 0.12 & 0.07 & 0.002 \\
\hline Uterine weight (g) & 5.88 & 3.09 & 0.64 & 0.03 \\
\hline Uterine length $(\mathrm{cm})$ & 7.17 & 5.75 & 0.40 & 0.07 \\
\hline Uterine weight:length ratio & 0.80 & 0.54 & 0.06 & 0.04 \\
\hline Caruncular endometrial thickness $(\mu \mathrm{m})$ & 874 & 735 & 43 & 0.03 \\
\hline Intercaruncular endometrial thickness $(\mu \mathrm{m})$ & 363 & 242 & 11 & $<0.0001$ \\
\hline Gland invaginations per section & 50.4 & 50.8 & 2.5 & 0.9 \\
\hline Gland number per section & 737.8 & 458.5 & 32.7 & $<0.0001$ \\
\hline Gland density (stratum compactum) & 2.45 & 2.88 & 0.13 & 0.02 \\
\hline Gland density (stratum spongiosum) & 9.18 & 8.50 & 0.26 & 0.07 \\
\hline Myometrial thickness $(\mu \mathrm{m})$ & 398 & 303 & 16 & $<0.0001$ \\
\hline
\end{tabular}

Myometrial thickness was reduced $(P<0.0001)$ by $24 \%$ in the uteri of Il ewes. The intercaruncular endometria of ++ ewes contained numerous coiled and slightly branched glands extending radially from the LE through the stroma to the inner circular layer of myometrium (Fig. 1). The intercaruncular endometria of II ewes also contained glands, but they were fewer in number (Fig. 1). Although the number of gland invaginations from the uterine lumen was not different $(P>0.10)$ between ++ and II ewes, the total number of endometrial glands in the uterus was reduced $(P<0.0001)$ by $38 \%$ in Il ewes. Gland density was $18 \%$ greater $(P<0.02)$ in the upper stratum compactum endometrium of II ewes, whereas gland density in the lower stratum spongiosum tended $(P<0.07)$ to be lower for the uteri of II ewes, suggesting a reduction in coiling and branching morphogenetic growth of the endometrial glands.

\section{Circulating levels of estradiol, testosterone, and inhibin in the Inverdale ewe}

The concentrations of $17 \beta$-estradiol, testosterone, and inhibin- $\alpha$ in plasma from ++ and II ewes between PNDs 0 and 56 are presented in Fig. 2.

\section{$17 \beta$-Estradiol}

The circulating concentrations of $17 \beta$-estradiol were affected by day $(P<0.0001)$, but not genotype or their interaction $(P>0.10)$. Overall, the concentrations of $17 \beta$ estradiol were the highest on PND $0(3.92 \pm 0.26 \mathrm{pg} / \mathrm{ml})$ and declined to low levels $(0.6-0.7 \mathrm{pg} / \mathrm{ml})$ thereafter (fifth-order effect of day, $P<0.02, r^{2}=0.61$ ).

\section{Testosterone}

The concentrations of testosterone in serum were affected by day and genotype (day $\times$ genotype, $P<0.002$ ). As illustrated in Fig. $2 \mathrm{~B}$, the concentrations of testosterone were low in ++ ewes on PND $0(0.34 \pm 0.08 \mathrm{ng} / \mathrm{ml})$ and remained relatively unchanged on PND $56(0.24 \mathrm{ng} / \mathrm{ml}$; quadratic effect of day, $P<0.05, r^{2}=0.12$ ). By contrast, the concentrations of testosterone in serum were high in II ewes on PND $0(0.90+0.09 \mathrm{ng} / \mathrm{ml})$, declined on PND 14 $(0.12 \mathrm{ng} / \mathrm{ml})$, and remained low thereafter (cubic effect of day, $\left.P<0.01, r^{2}=0.48\right)$.

\section{Inhibin- $\alpha$}

The circulating concentrations of inhibin- $\alpha$ were affected by day $(P<0.0001)$ and genotype $(P<0.0001)$, but not by their interaction. Overall, the concentrations of inhibin were about threefold higher $(P<0.0001)$ in ++ $(40.5 \pm 2.2 \mathrm{ng} / \mathrm{ml})$ compared with II $(16.6 \pm 2.2 \mathrm{ng} / \mathrm{ml})$ ewes. The circulating levels of inhibin declined from
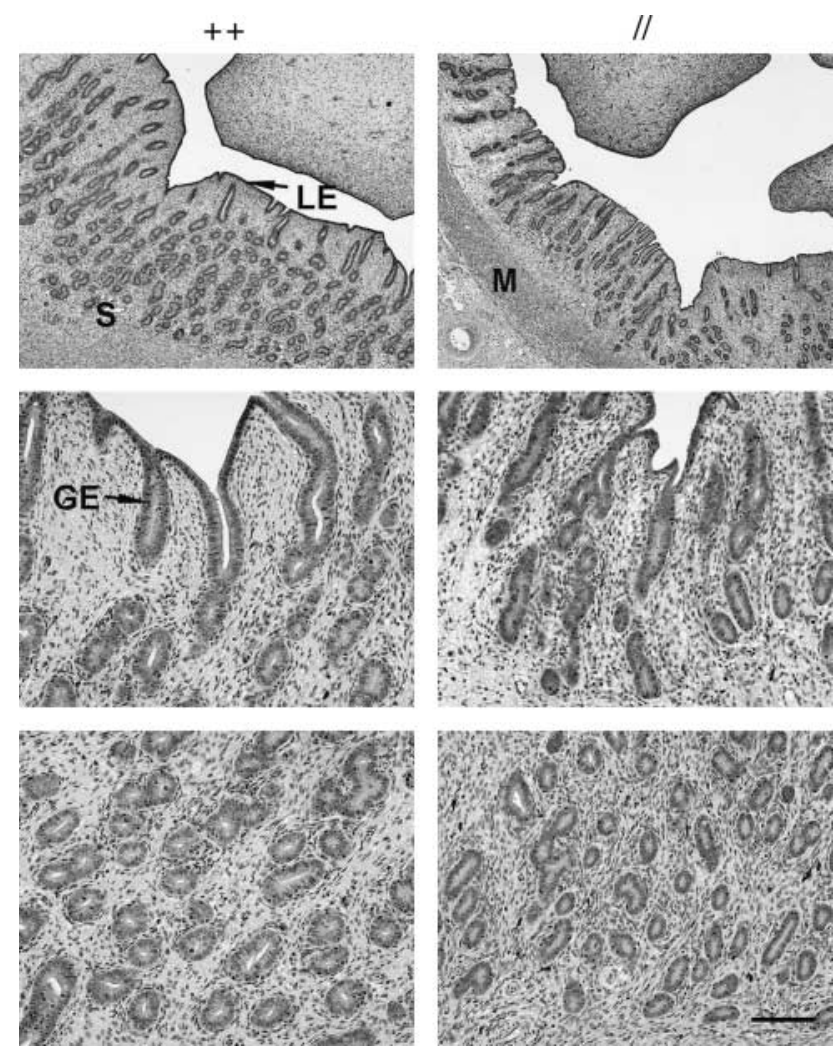

Figure 1 Representative photomicrographs illustrating the histoarchitecture of uteri from wild-type $(++)$ and homozygous (II) for Fec $X^{\prime}$ Inverdale ewes on postnatal day 56. LE, luminal epithelium; GE, glandular epithelium; S, stroma; M, myometrium. Scale bar=100 $\mu \mathrm{m}$. 

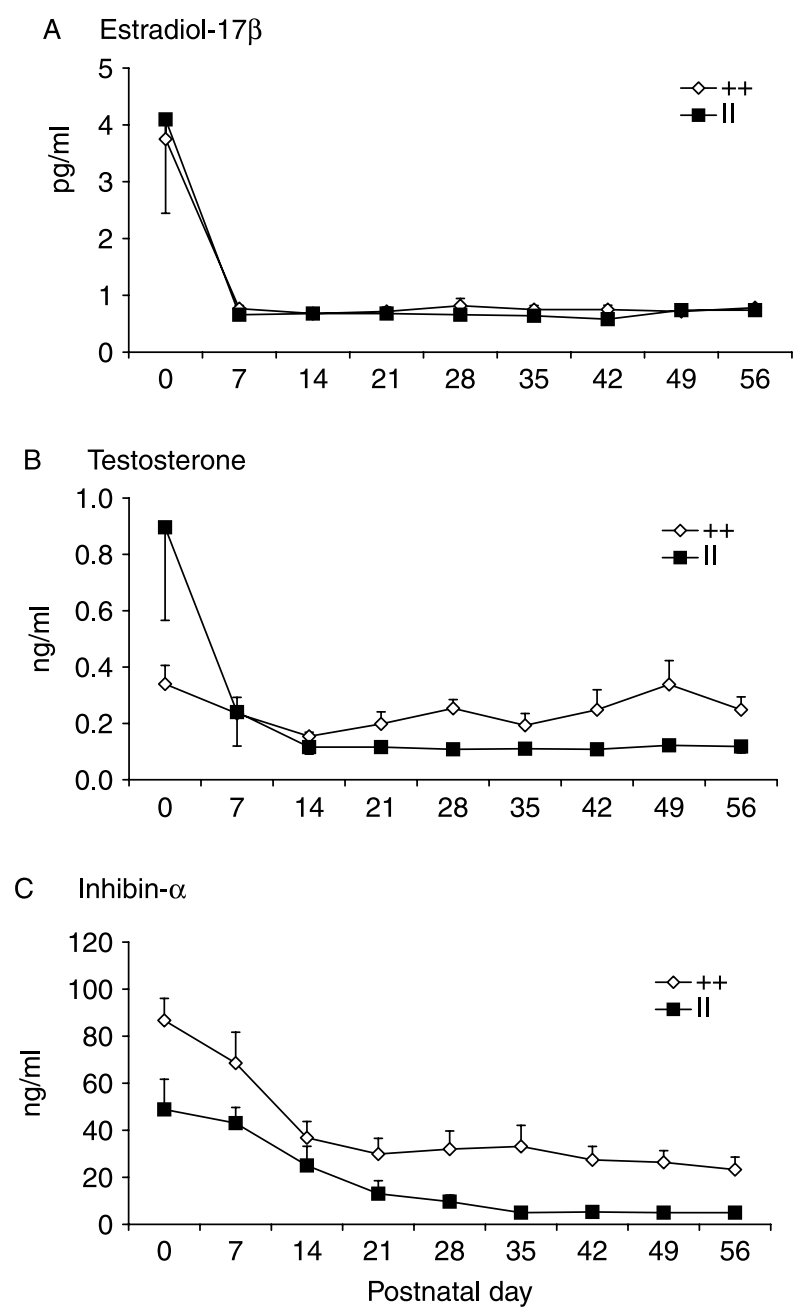

Figure 2 Concentrations of $17 \beta$-estradiol $(A)$, testosterone (B), and inhibin- $\alpha(C)$ in the serum from blood samples collected between postnatal days 0 and 56 from wild-type $(++)$ and homozygous Inverdale (II) ewes.

PNDs 0 to 56 in both ++ (cubic effect of day, $P<0.05$, $r^{2}=0.55$ ) and II ewes (quadratic effect of day, $P<0.001$, $\left.r^{2}=0.63\right)$.

\section{Androgen receptor and activin receptors in the neonatal uteri of Inverdale ewe}

Immunohistochemical analyses were performed to localize androgen receptor and activin receptor proteins in the uteri from ++ and II ewe lambs in Fig. 3. Overall, the abundance and pattern of androgen receptor, ActRIA, IB, and II proteins was not different in the uteri of ++ and II ewes.

\section{Androgen receptor}

Immunoreactive androgen receptor protein was detected in all uterine cell types and was most abundant in the endometrial LE and GE in both ++ and II ewes.

\section{ActRIA and IB}

ActRIA and IB proteins were detected in all cell types and were most abundant in endometrial LE and GE in both ++ and II ewes.

\section{ActRII}

In the uteri of both ++ and II ewes, ActRII protein was most abundant in endometrial LE, GE, and stroma. The antibody used for immunohistochemistry detects both ActRIIA and IIB (R\&D systems, Minneapolis, MN, USA).

\section{Discussion}

The results of this study strongly support the hypothesis that a uterotrophic factor emanating from the developing ovarian follicles regulates postnatal uterine growth and endometrial differentiation in neonatal ewes. Ovariectomy of the neonatal ewe at birth did not affect the initial genesis and development of endometrial glands on PND 14 (Bartol et al. 1988). However, ovariectomy of ewe lambs on PND 7 resulted in a $50 \%$ reduction in uterine wet weight by PND 56 (Carpenter et al. 2003a). Furthermore, ovariectomy of ewes on PND 7 results in reduced growth of the endometrium and myometrium, as well as the total number of uterine endometrial glands on PND 56 (Carpenter et al. 2003a). In the present study, II ewes mirrored the effects of neonatal ovariectomy on PND 7, because II ewes, on PND 56, had uteri with reduced weight, growth of the endometrium and myometrium, and also fewer endometrial glands. In addition, II ewes, on PND 56, had reduced uterine growth including reduced endometrial and myometrial thickness. In the neonatal ewes, treatment with either estrogen or progestins from birth or during critical developmental periods ablates endometrial adenogenesis, reduces uterine growth, and decreases endometrial and myometrial thickness (Gray et al. 2000, Carpenter et al. 2003 b, Hayashi et al. 2004). By contrast, treatment of neonatal ewes with prolactin from birth increases endometrial gland number and intercaruncular endometrial and myometrial thickness (Carpenter et al. 2003c). In fact, steroid disruption of uterine growth and endometrial adenogenesis in the neonatal ewe involves alterations in several growth factor systems including the IGFs, fibroblast growth factors, hepatocyte growth factor, WNTs, activin, and follistatin (Gray et al. 2000, Carpenter et al. 2003b, Hayashi et al. 2004, 2005, Hayashi \& Spencer 2005, 2006). Thus, endometrial and myometrial growth in ewes with the II genotype may result from changes in epithelial-mesenchymal interactions due to alterations in intrinsic growth factor pathways that decrease the development of endometrial glands.

In the present study, the uteri of II ewes had fewer endometrial glands, but no differences in the number of 


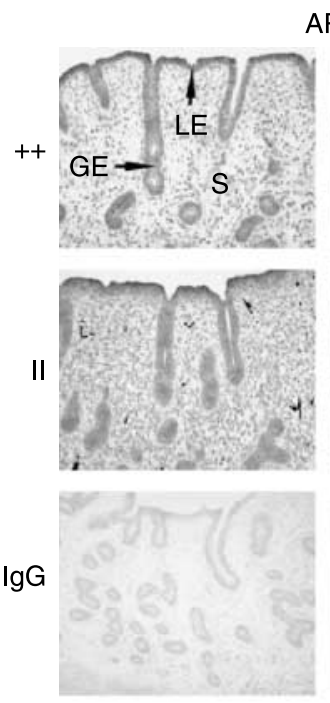

AR
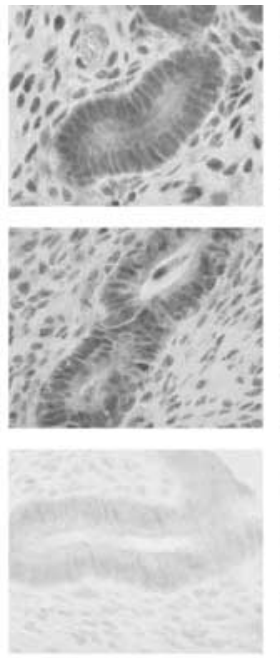

ActRIB
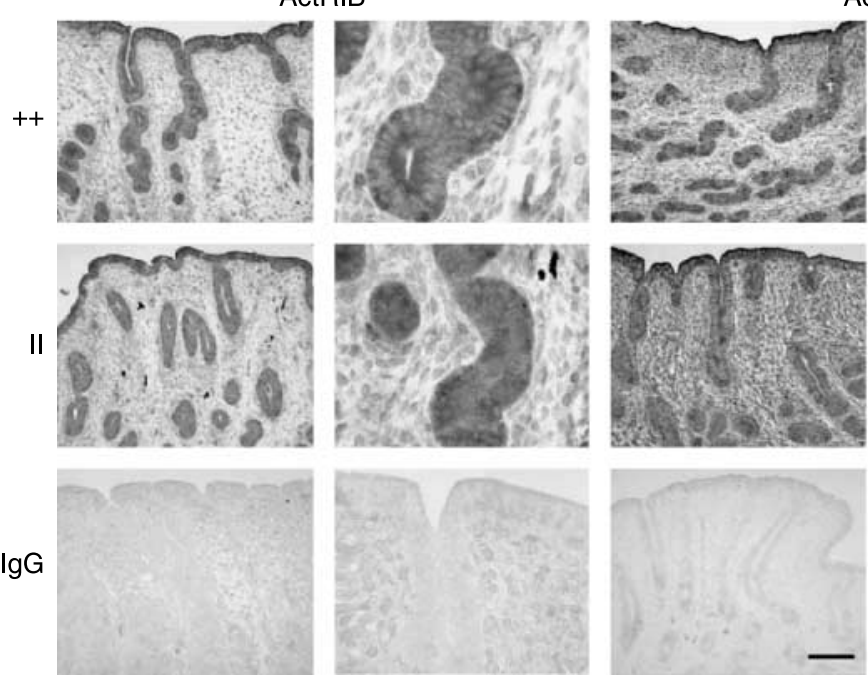

endometrial gland invaginations from the LE were detected. Initial genesis and development of endometrial glands between birth and PND 14 is not dependent on the ovary (Bartol et al. 1988) and ovariectomy does not affect the numbers of endometrial gland invaginations from the uterine lumen (Carpenter et al. 2003a). Therefore, budding differentiation of the endometrial glands from the LE must be regulated by local factors within the uterus. However, the results of the present study indicated that total number and density of endometrial glands in the stratum spongiosum stroma are reduced in uteri from II ewes, and this was also reported for ewes ovariectomized on PND 7 (Carpenter et al. 2003a). Therefore, an ovarian-derived factor regulates, in part, coiling and branching morphogenesis of endometrial gland development that occurs between PNDs 14 and 56 in the neonatal ewe.

Previous studies led to the hypothesis that the uterotrophic ovarian factor(s) was from the large
ActRIA

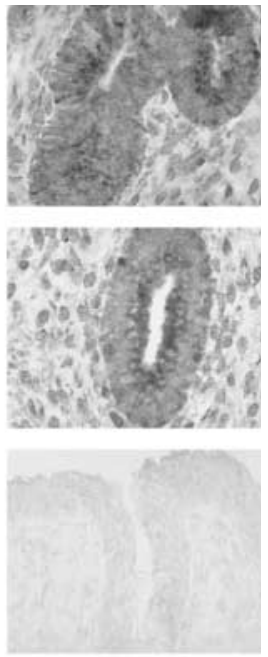

ActRII
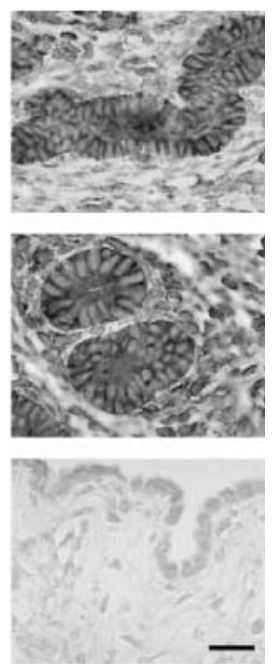

Figure 3 Immunohistochemical localization of androgen receptor (AR) and activin receptors (ActRIA, IB and II) in the uteri of ++ and II ewes. GE, glandular epithelium; LE, luminal epithelium; S, stroma. The scale bar indicates $100 \mu \mathrm{m}$ at low magnification and $25 \mu \mathrm{m}$ at high magnification.

number of developing follicles in the neonatal ovary (Carpenter et al. 2003a, Hayashi et al. 2003). The numbers of ovarian preantral and antral follicles in ewe lambs at birth (455 and 935 per ovary respectively) increase on PND 28 (683 and 1100 per ovary) and then decline on PND 84 (100 and 287 per ovary; Kennedy et al. 1974). These changes in the ovarian follicular dynamics are temporally correlated with rapid growth and development of the uterus and specifically the uterine glands in the neonatal ewe (Taylor et al. 2000). In II ewes, follicular development does not continue beyond the primary stage, which results in 'streak' ovaries without preantral (i.e., types 3 and 4 follicles) and antral follicles (Braw-Tal et al. 1993b. Smith et al. 1997). Thus, available results strongly support the hypothesis that the uterotrophic ovarian factor(s) is from the preantral and/or antral follicles in the neonatal ovine ovary. 
The nature of the uterotrophic ovarian factor(s) is not known, but available evidence indicates that the factor is not estrogen. Although numerous follicles are present in the neonatal ovine ovary, they do not synthesize or secrete appreciable amounts of estrogens between birth and PND 56 (Kennedy et al. 1974, Carpenter et al. $2003 \mathrm{~b}$ ). The developing preantral and antral follicles of the neonatal ovine ovary lack aromatase (K Hayashi, unpublished results), and ovariectomy on PND 7 did not affect circulating concentrations of estrogen between PNDs 7 and 56 (Carpenter et al. 2003a). In the present study, the circulating levels of $17 \beta$-estradiol were not different between ++ and II ewes. High concentrations of $17 \beta$-estradiol on PND 0 most likely reflect secretion by the maternal placenta during the periparturient period. Furthermore, administration of a non-steroidal aromatase inhibitor, CGS 20 267, from birth to PND 56 did not affect uterine growth or endometrial adenogenesis in the neonatal ewes (Carpenter et al. 2003b). Thus, there is no evidence to support a role for estrogens as regulators of uterine development in ewe lambs between PNDs 14 and 56.

A potential uterotrophic factor from ovarian follicles identified in the present study is testosterone. In the adult ovary, testosterone is synthesized by thecal cells of ovarian follicles (Shemesh \& Hansel 1976). Testosterone levels were higher in II ewes at birth and then lower than those for ++ ewes after PND 14, suggesting that testosterone, presumably from ovarian follicles, is affecting uterine growth and development. Indeed, the lack of conversion of testosterone to estrogen due to the absence of aromatase enzyme activity in the developing ovarian follicles may result in higher levels of circulating testosterone in the neonatal ewes. Androgen receptors are present in the uteri of a number of species including pigs, mice, and primates (Slayden et al. 2001, Pope \& Cardenas 2006). Similarly, the present study found that androgen receptor protein was present in all cell types in the neonatal ovine uterus, although no differences in abundance were detected between uteri of ++ and II ewes. Treatment of ovariectomized rats with testosterone restored uterine weight and increased IGF-I mRNA (Sahlin et al. 1994). Indeed, the intrinsic IGF-I system has been implicated in epithelial-stromal regulation of uterine growth and endometrial adenogenesis in the neonatal ewes (Taylor et al. 2001, Hayashi et al. 2004, 2005). Thus, further consideration of testosterone as an ovarian uterotrophic hormone in the neonatal ewe seems warranted.

Another potential ovarian-derived uterotrophic factor identified in the present study is inhibin- $\alpha$. Inhibins and activins are the members of the transforming growth factor- $\beta$ (TGF- $\beta$ ) superfamily, which regulate growth and differentiation of many branched epitheliomesenchymal organs, including mammary and prostate glands via autocrine, paracrine, and perhaps, endocrine mechanisms (Ritvos et al. 1995, Liu et al. 1996, Cancilla et al. 2001, Jones et al. 2006). Inhibins and activins are dimeric proteins (for review, see Welt et al. 2002, Jones et al. 2006). Activin consists of two $\beta$-subunits, $\beta$ A and $\beta B$, that homodimerize or heterodimerize to form activin $A(\beta A: \beta A)$, activin $B(\beta B: \beta B)$, or activin $A B$. In Inverdale ewes, inhibin- $\alpha$-subunit, activins, and follistatin are identified in small preantral follicles (type 3 ) and larger follicles in the wild-type ewes, but not in the follicles of II ewes that are only at the primordial (type 1) and primary (type 2) stages of follicular development (Juengel et al. 2000). In the neonatal ewe, activin subunits are present in the ovarian follicles (Carpenter et al. 2003a), endometrial LE and GE, and myometrium of the uterus (Hayashi et al. 2003). Inhibin consists of an $\alpha$-subunit that heterodimerizes with a $\beta$-subunit to form either inhibin $A(\beta A)$ or inhibin $B(\beta B)$; thus, inhibin- $\alpha$ can inhibit activin activity and vice versa. Inhibin- $\alpha$-subunit, activins, and follistatin are synthesized and secreted by the ovarian follicles of the neonate and the adult (Braw-Tal et al. 1993a, 1997, Braw-Tal 1994, McFarlane et al. 2002). In the neonatal ewe, inhibin- $\alpha$-subunit is present in the granulosa cells of growing and antral follicles, but not in the uterus (Carpenter et al. 2003a, Hayashi et al. 2003). The biological activity of activins is mediated by receptor complexes consisting of activin receptor (ActR) type IA or ActRIB and ActRII. In the neonatal ewe, activin receptors are found in all uterine cell types, but are most abundant in endometrial LE and $\mathrm{GE}$, and myometrium (Hayashi et al. 2003). One of the key features that distinguish the effects of activins from those of TGF- $\beta$ is that binding of activins to their receptors can be blocked if activin binds to follistatin or if the inhibin- $\alpha$-subunit binds to activin receptors (Ball \& Risbridger 2001). Follistatin binds to activins with high affinity and neutralizes their activity (Phillips \& de Kretser 1998). In the ewe, the circulating concentrations of follistatin increase in the fetus during parturition and remain relatively high until at least PND 7 (McFarlane et al. 2002). Follistatin is transcribed by the granulosa cells of growing and antral ovarian follicles in the neonatal ewes (Carpenter et al. 2003a) and also by the stromal and myometrial cells of the developing neonatal uterus between PNDs 21 and 56 (Hayashi et al. 2003). Available results support the hypothesis that inhibin, follistatin, activins, and activin receptors act as endocrine, autocrine, and/or paracrine regulators of uterine development and endometrial adenogenesis in the neonatal ewes (Carpenter et al. 2003a, Hayashi et al. 2003).

In the present study, the circulating levels of inhibin- $\alpha$ were significantly lower in the serum of II ewes from birth to PND 56 due to the lack of developing follicles in the streak ovary. Although follistatin was not measured in the present study, it is likely low in the II ewes, because follistatin is also synthesized and secreted by developing ovarian follicles (Braw-Tal et al. 1997, Carpenter et al. 2003a). As proposed for the effects of ovariectomy on 
uterine development in the neonatal ewes (Carpenter et al. 2003a), a reduction in the circulating levels of inhibin- $\alpha$-subunit and follistatin would increase the bioavailability of circulating activins and uterine-derived activins, which could retard uterine growth and endometrial adenogenesis. Studies of several epitheliomesenchymal organs, including salivary gland, pancreas, kidney, prostate gland, and mammary gland, indicate that exogenous activin inhibits gland development, whereas follistatin counteracts the inhibitory effects of activin by binding to individual $\beta A$ - and $\beta B$-subunits to prevent activin receptor activation (Ritvos et al. 1995, Liu et al. 1996, Ball \& Risbridger 2001, Cancilla et al. 2001).

Collectively, available evidence supports the hypothesis that a factor(s) from the ovary, such as testosterone, inhibin- $\alpha$, or follistatin, acts in an endocrine manner to regulate uterine growth and development in the neonatal ewes. The Inverdale ewe, lacking functional ovaries, is an excellent natural model for studies to define ovarian uterotrophic factors. Discovery of such factors could be useful in efforts to enhance uterine capacity and to take advantage of prolificacy genes and associated biotechnologies designed to increase reproductive performance of ewes. Furthermore, it will be important to examine the role of ovarian factors in the regulation of endometrial growth and development in the human uterus which, unlike uteri of domestic animals, must regenerate after menstruation during each menstrual cycle. Indeed, the activinfollistatin system is implicated in human endometrial growth and function (Jones et al. 2002, 2006).

\section{Materials and Methods}

\section{Animals and experimental design}

All experiments were performed with the approval of the Animal Ethics Committee at Invermay Agricultural Centre in accordance with the 1999 Animal Protection (Codes of Ethical Conduct) Regulations of New Zealand.

\section{Collection of tissue samples}

Ewe lambs either homozygous for the Inverdale mutation in BMP15 (II; $n=5)$ or their wild-type contemporaries $(++$; $n=6$ ) were identified by genotyping (Genomnz Laboratory, Mosgiel, New Zealand). Blood samples (1-3 ml) were obtained by jugular venipuncture on PNDs 0 (within $12 \mathrm{~h}$ of birth), 7, 14, $21,28,35,42,49$, and 56 to obtain serum for the analyses. After pentobarbital overdose on PND 56, the ovaries and uteri were removed from the ewe lambs, photographed, measured, and weighed. Cross-sections of the uterine horns were fixed in $4 \%$ paraformaldehyde in PBS for $24 \mathrm{~h}$ and then transferred to $70 \%$ ethanol until being embedded in paraffin.

\section{Determination of hormone concentrations}

Laboratory chemicals were obtained from BDH Chemicals New Zealand Ltd (Palmerston North, New Zealand); Roche Diagnostics N.Z. Ltd; ICPbio Ltd, Auckland, New Zealand (BSA); and GE Healthcare, Auckland, New Zealand (17 $\beta$-estradiol and testosterone tracer) respectively. The concentrations of $17 \beta$-estradiol, testosterone, and inhibin- $\alpha$ in serum from all blood samples were determined by RIA using the methods described previously (McNatty et al. 1981, 1992, Lun et al. 1998). The intra-assay coefficients of variation and assay sensitivities respectively were as follows: $6.6 \%$ and 0.05 $\mathrm{ng} / \mathrm{ml}$ for testosterone, $6.6 \%$ and $0.05 \mathrm{pg} / \mathrm{ml}$ for $17 \beta$-estradiol, and $11.0 \%$ and $5 \mathrm{IU} / \mathrm{ml}$ for inhibin- $\alpha$.

\section{Histology and morphometry}

Uteri were sectioned ( $5 \mu \mathrm{m}$ ) and stained with hematoxylin and eosin as described previously (Gray et al. 2001c, Hayashi et al. 2004). Uterine sections $(n=6)$ from each ewe were photomicrographed, and the images analyzed using Scion Image software (Scion Corporation, Frederick, MD, USA) as described previously (Carpenter et al. 2003b, 2003c, Hayashi et al. 2004). Measurements were standardized using the image of a stage micrometer at the same magnification. The number of superficial ductal invaginations of GE from LE into the stroma was determined. The criterion for ductal gland invagination was invagination of the GE into the underlying stroma with a length of more than $10 \mu \mathrm{m}$, which could be visibly tracked to a cross-section of a gland. Endometrial gland number was determined by counting the total number of uterine glands in a complete cross-section of the uterine horn. A gland crosssection with a visible open lumen was counted as a single uterine gland. Endometrial gland density was determined by counting the number of glands in a $0.04 \mathrm{~mm}^{2}$ area of the stratum compactum and stratum spongiosum areas of the intercaruncular endometrium. The number of ductal gland invaginations and endometrial gland number estimates were generated for at least three areas within five non-sequential sections from each uterine horn. Intra- and intersection estimates of repeatability for the determination of ductal gland invagination number and endometrial gland number by a single observer were 0.85 and 0.8 respectively. The thicknesses or widths of the intercaruncular and caruncular endometrium, as well as myometrium (inner circular and outer longitudinal layers), were measured using the Scion Image software from multiple points $(n=4)$ of at least ten nonsequential uterine sections.

\section{Immunohistochemistry}

Immunolocalization of androgen receptor and activin receptors (types IA, IB, and II) proteins was performed in the cross-sections $(5 \mu \mathrm{m})$ of paraffin-embedded uterine sections ( $n=6$ ewes per genotype) using specific antibodies and a Vectastain ABC Rabbit or Mouse IgG Kit (PK-6101 or PK-6102; Vector Laboratories, Burlingame, CA, USA). Rabbit polyclonal antibody to androgen receptor (sc-816, Santa Cruz Biotechnology Inc., Santa Cruz, CA, USA), and mouse monoclonal 
antibodies to ActRIA (MAB637; R\&D Systems Inc.), ActRIB (MAB222; R\&D Systems), and ActRII (MAB3391; R\&D Systems) were used for immunohistochemistry (Carpenter et al. 2003a, Hayashi et al. 2003, Juengel et al. 2006). All antibodies used in the experiments have been validated for ovine tissues in our laboratory. The working antibody concentrations for immunohistochemistry were $1.0 \mu \mathrm{g} / \mathrm{ml}$ for androgen receptor, ActRIA, IB, and II. Negative controls were performed, in which the primary antibody was substituted with the same concentration of normal rabbit or mouse IgG (SigmaAldrich). Antigen retrieval using a boiling citrate buffer was performed as described previously (Taylor et al. 2000). Multiple tissue sections from each ewe were processed as sets within an experiment. Sections were not counterstained before affixing the coverslip.

\section{Photomicroscopy}

Representative photomicrographs of the uterine tissues were taken using a Nikon Eclipse 1000 photomicroscope (Nikon Instruments Inc., Lewisville, TX, USA) fitted with a Nikon DXM1200 digital camera. Digital images were captured and assembled using Adobe Photoshop (Adobe Systems).

\section{Statistical analyses}

All quantitative data were subjected to least-squares analyses of variance (LS-ANOVA) using the general linear models procedures of the Statistical Analysis System (Cary, NC, USA). Histomorphometrical data were analyzed using an overall model that included main effects of genotype, section, and area, as well as their interactions. RIA data were analyzed using a model to determine the effects of day, genotype, and their interaction. In all analyses, error terms used in tests of significance were identified according to the expectation of the mean squares for error. Data were then analyzed by leastsquares regression analyses to determine the effects of day within genotype. $P \leq 0.05$ was accepted as indicating significance. Data are presented as least-square means of untransformed values with overall S.E.M.

\section{Acknowledgements}

The technical assistance of Stan Lun and Norma Hudson is greatly appreciated for hormone assays. The authors declare that there is no conflict of interest that would prejudice the impartiality of this scientific work.

\section{References}

Ball EM \& Risbridger GP 2001 Activins as regulators of branching morphogenesis. Developmental Biology 238 1-12.

Bartol FF, Wiley AA \& Goodlett DR 1988 Ovine uterine morphogenesis: histochemical aspects of endometrial development in the fetus and neonate. Journal of Animal Science 66 1303-1313.

Bartol FF, Johnson LL, Floyd JG, Wiley AA, Spencer TE, Buxton DF \& Coleman DA 1995 Neonatal exposure to progesterone and estradiol alters uterine and morphology and luminal protein content in adult beef Heifers. Theriogenology 43 835-844.
Bartol FF, Wiley AA, Floyd JG, Ott TL, Bazer FW, Gray CA \& Spencer TE 1999 Uterine differentiation as a foundation for subsequent fertility. Journal of Reproduction and Fertility 54 287-302.

Braw-Tal R 1994 Expression of mRNA for follistatin and inhibin/activin subunits during follicular growth and atresia. Journal of Molecular Endocrinology 13 253-264.

Braw-Tal R, Bor A \& Gootwine E 1993a Plasma immunoreactive inhibin and FSH in prepubertal Assaf and Booroola-Assaf ewe lambs. Domestic Animal Endocrinology 10 87-94.

Braw-Tal R, McNatty KP, Smith P, Heath DA, Hudson NL, Phillips DJ, McLeod BJ \& Davis GH 1993b Ovaries of ewes homozygous for the X-linked Inverdale gene (FecXI) are devoid of secondary and tertiary follicles but contain many abnormal structures. Biology of Reproduction 49 895-907.

Braw-Tal R, Yossefi S, Zenou A \& Bor A 1997 Differential expression pattern of inhibin alpha and betaA subunits in the ovaries of postnatal and prepubertal lambs. Reproduction, Fertility, and Development 9 825-832.

Burton GJ, Watson AL, Hempstock J, Skepper JN \& Jauniaux E 2002 Uterine glands provide histiotrophic nutrition for the human fetus during the first trimester of pregnancy. Journal of Clinical Endocrinology and Metabolism 87 2954-2959.

Cancilla B, Jarred RA, Wang H, Mellor SL, Cunha GR \& Risbridger GP 2001 Regulation of prostate branching morphogenesis by activin $\mathrm{A}$ and follistatin. Developmental Biology 237 145-158.

Carpenter KD, Hayashi K \& Spencer TE 2003a Ovarian regulation of endometrial gland morphogenesis and activin-follistatin system in the neonatal ovine uterus. Biology of Reproduction 69 851-860.

Carpenter KD, Gray CA, Bryan TM, Welsh TH Jr \& Spencer TE $2003 b$ Estrogen and antiestrogen effects on neonatal ovine uterine development. Biology of Reproduction 69 708-717.

Carpenter KD, Gray CA, Noel S, Gertler A, Bazer FW \& Spencer TE 2003 C Prolactin regulation of neonatal ovine uterine gland morphogenesis. Endocrinology 144 110-120.

Davis GH, McEwan JC, Fennessy PF, Dodds KG \& Farquhar PA 1991 Evidence for the presence of a major gene influencing ovulation rate on the X chromosome of sheep. Biology of Reproduction 44 620-624.

Davis GH, McEwan JC, Fennessy PF, Dodds KG, McNatty KP \& O WS 1992 Infertility due to bilateral ovarian hypoplasia in sheep homozygous (FecXI FecXI) for the Inverdale prolificacy gene located on the $\mathrm{X}$ chromosome. Biology of Reproduction 46 636-640.

Galloway SM, McNatty KP, Cambridge LM, Laitinen MP, Juengel JL, Jokiranta TS, McLaren RJ, Luiro K, Dodds KG, Montgomery GW et al. 2000 Mutations in an oocyte-derived growth factor gene (BMP15) cause increased ovulation rate and infertility in a dosage-sensitive manner. Nature Genetics 25 279-283.

Galloway SM, Gregan SM, Wilson T, McNatty KP, Juengel JL, Ritvos O \& Davis GH 2002 Bmp15 mutations and ovarian function. Molecular and Cellular Endocrinology 191 15-18.

Gray CA, Taylor KM, Bazer FW \& Spencer TE 2000 Mechanisms regulating norgestomet inhibition of endometrial gland morphogenesis in the neonatal ovine uterus. Molecular Reproduction and Development $\mathbf{5 7}$ $67-78$.

Gray CA, Bazer FW \& Spencer TE 2001a Effects of neonatal progestin exposure on female reproductive tract structure and function in the adult ewe. Biology of Reproduction 64 797-804.

Gray CA, Bartol FF, Tarleton BJ, Wiley AA, Johnson GA, Bazer FW \& Spencer TE $2001 b$ Developmental biology of uterine glands. Biology of Reproduction 65 1311-1323.

Gray CA, Taylor KM, Ramsey WS, Hill JR, Bazer FW, Bartol FF \& Spencer TE 2001c Endometrial glands are required for preimplantation conceptus elongation and survival. Biology of Reproduction 64 1608-1613.

Gray CA, Burghardt RC, Johnson GA, Bazer FW \& Spencer TE 2002 Evidence that absence of endometrial gland secretions in uterine gland knockout ewes compromises conceptus survival and elongation. Reproduction 124 289-300.

Hayashi K \& Spencer TE 2005 Estrogen disruption of neonatal ovine uterine development: effects on gene expression assessed by suppression subtraction hybridization. Biology of Reproduction 73 752-760.

Hayashi K \& Spencer TE 2006 WNT pathways in the neonatal ovine uterus: potential specification of endometrial gland morphogenesis by SFRP2. Biology of Reproduction 74 721-733. 
Hayashi K, Carpenter KD, Gray CA \& Spencer TE 2003 The activinfollistatin system in the neonatal ovine uterus. Biology of Reproduction 69 843-850.

Hayashi K, Carpenter KD \& Spencer TE 2004 Neonatal estrogen exposure disrupts uterine development in the postnatal sheep. Endocrinology 145 3247-3257.

Hayashi K, Carpenter KD, Welsh TH Jr, Burghardt RC, Spicer LJ \& Spencer TE 2005 The IGF system in the neonatal ovine uterus. Reproduction 129 337-347.

Jones RL, Salamonsen LA \& Findlay JK 2002 Potential roles for endometrial inhibins, activins and follistatin during human embryo implantation and early pregnancy. Trends in Endocrinology and Metabolism 13 144-150.

Jones RL, Stoikos C, Findlay JK \& Salamonsen LA 2006 TGF-beta superfamily expression and actions in the endometrium and placenta. Reproduction 132 217-232.

Juengel JL, Quirke LD, Tisdall DJ, Smith P, Hudson NL \& McNatty KP 2000 Gene expression in abnormal ovarian structures of ewes homozygous for the Inverdale prolificacy gene. Biology of Reproduction 62 1467-1478.

Juengel JL, Sawyer HR, Smith PR, Quirke LD, Heath DA, Lun S, Wakefield SJ \& McNatty KP 2002 Origins of follicular cells and ontogeny of steroidogenesis in ovine fetal ovaries. Molecular and Cellular Endocrinology 191 1-10.

Juengel JL, Heath DA, Quirke LD \& McNatty KP 2006 Oestrogen receptor alpha and beta, androgen receptor and progesterone receptor mRNA and protein localisation within the developing ovary and in small growing follicles of sheep. Reproduction 131 81-92.

Kennedy JP, Worthington CA \& Cole ER 1974 The post-natal development of the ovary and uterus of the Merino lamb. Journal of Reproduction and Fertility 36 275-282.

Liu QY, Niranjan B, Gomes P, Gomm JJ, Davies D, Coombes RC \& Buluwela L 1996 Inhibitory effects of activin on the growth and morpholgenesis of primary and transformed mammary epithelial cells. Cancer Research 56 1155-1163.

Lun S, Smith P, Lundy T, O'Connell A, Hudson N \& McNatty KP 1998 Steroid contents of and steroidogenesis in vitro by the developing gonad and mesonephros around sexual differentiation in fetal sheep. Journal of Reproduction and Fertility 114 131-139.

McFarlane JR, Xia Y, O'Shea T, Hayward S, O'Connor AE \& De Kretser DM 2002 Follistatin concentrations in maternal and fetal fluids during the oestrous cycle, gestation and parturition in Merino sheep. Reproduction 124 259-265.

McNatty KP, Gibb M, Dobson C, Thurley DC \& Findlay JK 1981 Changes in the concentration of gonadotropic and steroidal hormones in the antral fluid of ovarian follicle throughout the oestrous cycle of the sheep. Australian Journal of Biological Sciences 34 67-80.

McNatty KP, Heath DA, Hudson NL, Ball K \& Condell L 1992 Concentrations of immunoreactive inhibin in ovarian and peripheral venous plasma and follicular fluid of Booroola ewes that are homozygous carriers or non-carriers of the FecB gene. Journal of Reproduction and Fertility 95 489-502.

Phillips DJ \& de Kretser DM 1998 Follistatin: a multifunctional regulatory protein. Frontiers in Neuroendocrinology 19 287-322.

Pope WF \& Cardenas H 2006 Androgens in female pig reproduction: actions mediated by the androgen receptor. Society of Reproduction and Fertility 62 55-67.
Ritvos O, Tuuri T, Eramaa M, Sainio K, Hilden K, Saxen L \& Gilbert SF 1995 Activin disrupts epithelial branching morphogenesis in developing glandular organs of the mouse. Mechanisms of Development 50 229-245.

Sahlin L, Norstedt G \& Eriksson H 1994 Androgen regulation of the insulin-like growth factor-I and the estrogen receptor in rat uterus and liver. Journal of Steroid Biochemistry and Molecular Biology $\mathbf{5 1}$ 57-66.

Shackell GH, Hudson NL, Heath DA, Lun S, Shaw L, Condell L, Blay LR \& McNatty KP 1993 Plasma gonadotropin concentrations and ovarian characteristics in Inverdale ewes that are heterozygous for a major gene (FecX1) on the X chromosome that influences ovulation rate. Biology of Reproduction 48 1150-1156.

Shemesh M \& Hansel W 1976 Steroid synthesis by ovarian follicles in response to LH and PGF2alpha. Proceedings of the Society for Experimental Biology and Medicine 152 86-89.

Slayden OD, Nayak NR, Burton KA, Chwalisz K, Cameron ST, Critchley HO, Baird DT \& Brenner RM 2001 Progesterone antagonists increase androgen receptor expression in the rhesus macaque and human endometrium. Journal of Clinical Endocrinology and Metabolism 86 2668-2679.

Smith P, O WS, Corrigan KA, Smith T, Lundy T, Davis GH \& McNatty KP 1997 Ovarian morphology and endocrine characteristics of female sheep fetuses that are heterozygous or homozygous for the Inverdale prolificacy gene (fecX1). Biology of Reproduction 57 1183-1192.

Spencer TE, Hayashi K, Hu J \& Carpenter KD 2005a Comparative developmental biology of the mammalian uterus. Current Topics in Developmental Biology 68 85-122.

Spencer TE, Carpenter KD, Hayashi K \& Hu J $2005 b$ Uterine glands. In Branching Morphogenesis, Ed. JA Davies. Georgetown: Landes Biosciences.

Stewart CL, Kaspar P, Brunet LJ, Bhatt H, Gadi I, Kontgen F \& Abbondanzo SJ 1992 Blastocyst implantation depends on maternal expression of leukaemia inhibitory factor. Nature 359 76-79.

Tassell R, Chamley WA \& Kennedy JP 1978 Gonadotrophin levels and ovarian development in the neonatal ewe lamb. Australian Journal of Biological Sciences 31 267-273.

Taylor KM, Gray CA, Joyce MM, Stewart MD, Bazer FW \& Spencer TE 2000 Neonatal ovine uterine development involves alterations in expression of receptors for estrogen, progesterone, and prolactin. Biology of Reproduction 63 1192-1204.

Taylor KM, Chen C, Gray CA, Bazer FW \& Spencer TE 2001 Expression of messenger ribonucleic acids for fibroblast growth factors 7 and 10 , hepatocyte growth factor, and insulin-like growth factors and their receptors in the neonatal ovine uterus. Biology of Reproduction 64 1236-1246.

Welt C, Sidis Y, Keutmann H \& Schneyer A 2002 Activins, inhibins, and follistatins: from endocrinology to signaling. A paradigm for the new millennium. Experimental Biology and Medicine 227 724-752.

Wiley AA, Bartol FF \& Barron DH 1987 Histogenesis of the ovine uterus. Journal of Animal Science 64 1262-1269.

Zhu LJ, Bagchi MK \& Bagchi IC 1998 Attenuation of calcitonin gene expression in pregnant rat uterus leads to a block in embryonic implantation. Endocrinology 139 330-339.

Received 12 July 2007

First decision 7 September 2007

Accepted 1 November 2007 